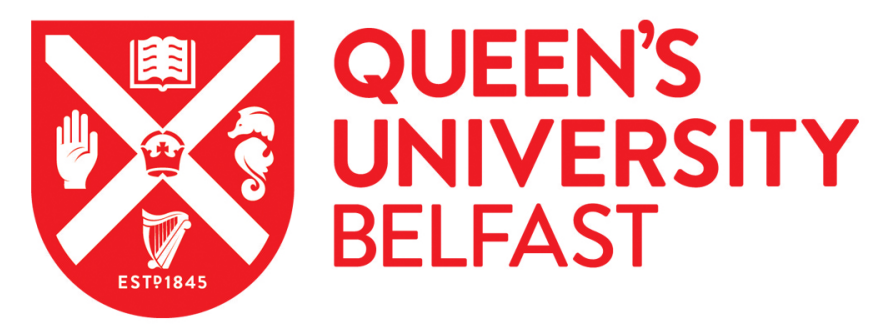

\title{
Diversity and zonal distribution of arbuscular mycorrhizal fungi on the northern slopes of the Tianshan Mountains
}

Shi, Z. Y., Chen, Z. C., Zhang, L. Y., Feng, G., Christie, P., Tian, C. Y., \& Li, X. L. (2007). Diversity and zonal distribution of arbuscular mycorrhizal fungi on the northern slopes of the Tianshan Mountains. Science in China Series $D$ - Earth Sciences, 50 (Suppl. 1)(SUPPL. 1), 135-141. https://doi.org/10.1007/s11430-007-5014-5

Published in:

Science in China Series D - Earth Sciences

Queen's University Belfast - Research Portal:

Link to publication record in Queen's University Belfast Research Portal

\section{General rights}

Copyright for the publications made accessible via the Queen's University Belfast Research Portal is retained by the author(s) and / or other copyright owners and it is a condition of accessing these publications that users recognise and abide by the legal requirements associated with these rights.

Take down policy

The Research Portal is Queen's institutional repository that provides access to Queen's research output. Every effort has been made to ensure that content in the Research Portal does not infringe any person's rights, or applicable UK laws. If you discover content in the Research Portal that you believe breaches copyright or violates any law, please contact openaccess@qub.ac.uk. 


\title{
Diversity and zonal distribution of arbuscular my- corrhizal fungi on the northern slopes of the Tianshan Mountains
}

\author{
SHI ZhaoYong ${ }^{1,2}$, CHEN ZhiChao $^{1}$, ZHANG LiYun ${ }^{1}$, FENG Gu ${ }^{2 \dagger}$, CHRISTIE Peter $^{2,3}$, \\ TIAN ChangYan ${ }^{1} \&$ LI XiaoLin ${ }^{2}$ \\ ${ }^{1}$ Xinjiang Institute of Ecology and Geography, Chinese Academy of Sciences,Ürümqi 830011, China; \\ ${ }^{2}$ College of Resources and Environmental Sciences, China Agricultural University, Beijing 100094, China; \\ ${ }^{3}$ Queen's University Belfast, Agricultural and Environmental Science Department, Newforge Lane, Belfast BT9 5PX, UK
}

The arbuscular mycorrhizal (AM) fungal status of the 20 most common plant species distributed in 4 vegetation types (meadow steppe, desert steppe, steppe desert and typical desert) on the northern slopes of the Tianshan Mountains was investigated. Samples of the plant species and their rhizosphere soils were collected from the 4 vegetation zones and examined to compare their mycorrhizal status, AM fungal spore densities, biovolumes, and community structures. 28 AM fungal species were isolated from the rhizosphere soils: of these, 5 belonged to Acaulospora, 1 to Archaeospora and 22 to Glomus. 5 AM fungi, Glomus aggregatum, G. claroideum, G. deserticola, G. etunicatum and G. sinuosum, were observed in all 4 zonal types. No significant differences were observed in mean proportion of root length colonized by AM fungi among the plant species within each zonal type. Comparing the 4 zonal types, Plantago minuta (84.5\%) in steppe desert and Eremopyrum orientale (83.1\%) in typical desert showed the highest root colonizatsion rates. AM fungal spore densities and biovolumes were significantly different in the different zonal types. AM fungal spore densities and biovolumes, species richness and diversity were highest in meadow steppe and lowest in typical desert.

northern slopes, Tianshan Mountains, arbuscular mycorrhizal fungi, spore densities, diversity, zonal distribution

The concept of the ecosystem is predominantly rooted in biogeochemical processes with emphasis on the transfers of materials and energy between abiotic and biotic compartments $^{[1]}$. The pivotal involvement of arbuscular mycorrhizal (AM) fungi in plant mineral nutrition ${ }^{[2,3]}$ places these fungi at the abiotic/biotic interface in ecosystems. Rillig ${ }^{[4]}$ reviewed the pathways of influence of AM fungi to ecosystem processes and recognized 4 aspects in which they act: (1) by influencing plant community composition, (2) by influencing soil microbial communities, (3) by mediating changes in (individual) host physiology and resource capture, and (4) by direct effects of the AM fungal mycelium and its products in soil. As a result of this unique situation AM fungi have been described as "keystone mutualists" in terres- trial ecosystems ${ }^{[5]}$.

AM fungi establish broadly distributed and possibly symbiotic associations with the majority ( $80 \%$ ) of higher plant species ${ }^{[3]}$ and may potentially have played an important role in terrestrial ecosystems for over $460 \mathrm{Ma}^{[6]}$. They are responsive to many perturbations that act at the ecosystem level such as factors of global change ${ }^{[7-10]}$, agricultural management practices ${ }^{[11-13]}$, or pollution (e.g., heavy metals ${ }^{[14]}$ ) and nitrogen deposition ${ }^{[15]}$.

The relationship between terrestrial ecosystems and

\footnotetext{
Received May 12, 2006; accepted February 10, 2007 doi: 10.1007/s11430-007-5014-5

${ }^{\dagger}$ Corresponding author (email: fenggu@cau.edu.cn)

Supported by the National Natural Science Foundation of China (Grant Nos. 40661008 and 30470341) and the Opening Foundation of Xinjiang Institute of Ecology and Geography, Chinese Academy of Sciences
} 
climate change is one of the most important fields in the study of global change and the relationship between vegetation and climate change is one of the main research focuses ${ }^{[16-18]}$. The degree of biological response in different climatic regions to global change on a range of temporal and spatial scales has, therefore, become a topical research area in recent years. Of particular interest, is the sensitivity of ecosystems in arid areas ${ }^{[19]}$. AM symbionts must be considered in investigations of plant biodiversity and ecosystem function ${ }^{[20]}$. Consequently, the relationship between AM fungal diversity and global change has become an important scientific focus.

Xinjiang Autonomous Region, located in the hinterland of Eurasia, has unique landforms that play an important role in the climatic conditions in this arid part of northwest China. Global change and violent disturbances resulting from human activities have resulted in significant climatic and environmental changes in Xinjiang $^{[21]}$ and these responses to global climate change have been studied in some detail ${ }^{[22]}$. Both temperature and precipitation appear to have increased on the northern slopes of the Tianshan Mountains over the last two decades and the climate has changed from a warm-dry type to a warm-humid type ${ }^{[23]}$. This has led to much interest in the question of how ecosystems and plant communities respond to climate change ${ }^{[19]}$ and, because they play such an important role in the ecosystem, the responses of AM fungi may be crucial. The objectives of the present survey were to investigate AM fungal colonization and developmental status of desert ephemerals and AM fungal communities in 4 different vegetation types on the northern slopes of the Tianshan Mountains to elucidate the relationship between AM fungal diversity and global change.

\section{Materials and Methods}

\subsection{Study sites}

AM fungal diversity was investigated in 4 vertical zonal types on the northern slopes of the Tianshan Mountains in May 2005 (Table 1). Samples of roots and soil (ca. $100 \mathrm{~g}$ ) were collected from the rhizosphere of each plant listed in Table 1 in each zonal type. 20 individuals of each plant species were collected and these were separated into 4 portions. Care was taken during collection of individual plants to ensure that roots could be clearly identified as belonging to a particular plant. Samples were taken to the laboratory for determination

Table 1 Descriptions of sampling sites in the 4 vegetation types

\begin{tabular}{|c|c|c|c|c|c|c|c|}
\hline \multirow[b]{2}{*}{ Zonal type } & \multirow{2}{*}{$\begin{array}{c}\text { Site location and } \\
\text { elevation }\end{array}$} & \multirow[b]{2}{*}{ Soil type } & \multicolumn{4}{|c|}{ Soil physico-chemical properties } & \multirow[b]{2}{*}{ Host plant species } \\
\hline & & & $\begin{array}{c}\text { Organic } \\
\text { matter }(\mathrm{g} / \mathrm{kg})\end{array}$ & $\begin{array}{c}\text { Available P } \\
(\mathrm{mg} / \mathrm{kg})\end{array}$ & $\mathrm{pH}$ & $\begin{array}{l}\text { Electrical conductivity } \\
(\mathrm{mS} / \mathrm{cm})\end{array}$ & \\
\hline Meadow steppe & $\begin{array}{l}44^{\circ} 31.906^{\prime} \mathrm{N} \\
81^{\circ} 18.375^{\prime} \mathrm{E} \\
2100 \mathrm{~m}\end{array}$ & Chestnut soil & 58.92 & 9.73 & 8.03 & 0.55 & $\begin{array}{l}\text { Potentilla sp. } \\
\text { Stipa capillata } \\
\text { Androsace sp. } \\
\text { Taraxacum } \mathrm{sp} .\end{array}$ \\
\hline Desert steppe & $\begin{array}{l}44^{\circ} 36.898^{\prime} \mathrm{N} \\
81^{\circ} 45.089^{\prime} \mathrm{E} \\
1100 \mathrm{~m}\end{array}$ & $\begin{array}{l}\text { Light } \\
\text { chestnut soil }\end{array}$ & 15.42 & 10.43 & 8.15 & 0.33 & $\begin{array}{l}\text { Allium polyrrhizum } \\
\text { Orostachys sp. } \\
\text { Cleistogenes songgorica } \\
\text { Stipa glareosa }\end{array}$ \\
\hline Steppe desert & $\begin{array}{l}44^{\circ} 37.324^{\prime} \mathrm{N} \\
81^{\circ} 51.004^{\prime} \mathrm{E} \\
830 \mathrm{~m}\end{array}$ & $\begin{array}{l}\text { Grey brown } \\
\text { desert soil }\end{array}$ & 5.15 & 6.23 & 8.73 & 0.33 & $\begin{array}{l}\text { Ceratoides latens } \\
\text { Salsola arbuscula } \\
\text { Allium polyrrhizum } \\
\text { Cleistogenes songgorica } \\
\text { Plantago minuta } \\
\text { Trigonella arcuata } \\
\text { Nonea caspica }\end{array}$ \\
\hline Typical desert & $\begin{array}{l}44^{\circ} 27.010^{\prime} \mathrm{N} \\
83^{\circ} 55.098^{\prime} \mathrm{E} \\
525 \mathrm{~m}\end{array}$ & Gobi desert & 5.00 & 4.26 & 7.94 & 0.82 & $\begin{array}{l}\text { Plantago minuta } \\
\text { Erodiun oxyrrhynchum } \\
\text { Cancrinia discoidea } \\
\text { Heliotropium ellipticum } \\
\text { Lactuca } \text { sp. } \\
\text { Eremopyrum orientale } \\
\text { Arnebia guttata } \\
\text { Atriplex dimorphostegia }\end{array}$ \\
\hline
\end{tabular}


of the proportion of total root length colonized by AM fungi. Soil samples were air-dried prior to extraction, counting and identification of spores using standard methods.

\subsection{Assessment of AM colonization}

Fresh roots were processed by washing them with water to remove soil, followed by clearing with $10 \%(\mathrm{w} / \mathrm{v})$ $\mathrm{KOH}$ in a $90^{\circ} \mathrm{C}$ water bath for between $15-30 \mathrm{~min}$, depending on the degree of lignification of the roots and their pigmentation. The cooled root samples were washed, cut into 0.5 - to $1.0-\mathrm{cm}$-long segments and stained with $0.5 \%(\mathrm{w} / \mathrm{v})$ acid fuchsin ${ }^{[24]}$. The percentage of root length colonized by AM fungal structures was determined using the magnified line-intersect method of McGonigle et al. ${ }^{[25]}$.

\subsection{Recovery and counts of AM fungal spores}

Spores or sporocarps were extracted from $30 \mathrm{~g}$ air-dried subsamples of each soil sample by wet sieving followed by flotation-centrifugation in $50 \%$ sucrose $^{[26]}$. The finest sieve used was $53 \mu \mathrm{m}$. Spores were collected on grid-patterned $(4 \mathrm{~mm} \times 4 \mathrm{~mm})$ filter paper, washed three times with distilled water to spread them evenly over the entire grid and counted using a dissecting microscope at $\times 30$ magnification. A sporocarp was counted as one spore.

\subsection{Numbers and distribution of AM fungal spores}

Species richness, spore density and frequency of AM fungi were expressed as follows: spore density (SD)= number of AM fungal spores in $30 \mathrm{~g}$ soil; species richness $(\mathrm{SR})=$ number of AM fungal taxa found in $30 \mathrm{~g}$ soil sample; frequency $(\mathrm{F})=$ (number of samples in which the species or genus was observed/total samples) $\times 100 \%$. Species diversity was assessed by the Shannon-Weiner index and Simpson index as follows:

$$
\begin{gathered}
\text { Shannon-Weiner index }(H)=-\Sigma\left(P_{i} \cdot \ln \left[P_{i}\right]\right), \\
\text { Simpson index }(D)=1-\Sigma\left(P_{i}\right)^{2} ;
\end{gathered}
$$

where $P_{i}=n_{i} / N$ and $n_{i}=$ number of individuals in species $i$ and $N=$ total number of individuals in all species.

Species evenness was assessed as follows: ShannonWeiner index $J=$ Shannon $H / \operatorname{lnSR}$

Spore biovolume was calculated as $V=1 / 6 \pi D^{3}$ for species with spherical spores, or as $V=1 / 6 \pi D_{1} D_{2}^{2}$ (where $D_{1}$ is the larger dimension and $D_{2}$ is the smaller dimension) for species with elongated spores ${ }^{[27]}$.

\subsection{Identification of AM fungi}

Spore identification was based mainly on spore size, colour, wall structure and hyphal attachment ${ }^{[28]}$. Spore identification was corroborated by comparisons with descriptions from the reference cultures in INVAM (http://invam.cag.wvu.edu) and the IBG (International Bank for the Glomales, formerly named La Banque Europeene de Glomales). AM fungal spores were classified according to the taxonomic system of Morton and Redecker $^{[29]}$.

\subsection{Statistical analysis}

One-way analysis of variance (ANOVA) was used to test for differences in AM fungal index in the 4 different vegetation zones using the SPSS software package version 11.0. Pairs of mean values were compared using least significant difference (LSD) at the $5 \%$ level.

\section{Results}

\subsection{Comparison of AM fungal colonization status, spore densities and biovolume in the $\mathbf{4}$ zonal types}

AM fungal colonization status, spore densities and biovolumes in the 4 zonal types are shown in Figure 1. The mean mycorrhizal colonization rates in meadow steppe, desert steppe, steppe desert and typical desert were $28.1 \%, 19.6 \%, 33.7 \%$ and $23.3 \%$, respectively and no significant differences were observed among the 4 zonal types $(p>0.05$; Figure 1(a)). Spore densities and biovolumes were significantly higher in meadow steppe than in the other three zonal types, with mean values of 75.0 spores $/ 30 \mathrm{~g}$ soil and $9.03 \mathrm{~mm}^{3} / 30 \mathrm{~g}$ soil (Figure 1(b), (c)). The lowest spore densities and biovolumes were found in typical desert, with an average of 7.1 spores and $0.55 \mathrm{~mm}^{3} / 30 \mathrm{~g}$ soil (Figure 1(b), (c)).

The mycorrhizal colonization rates of all plant species and spore densities of their rhizosphere soils in all zonal type are shown in Table 2. The mycorrhizal colonization rates of Plantago minuta $(84.5 \%)$ in steppe desert and Eremopyrum orientale $(83.1 \%)$ in typical desert were significantly higher than those of the other plant species. The highest spore densities found were associated with Taraxacum sp. in meadow steppe, with an average of 150 spores/30 g soil.

2.2 Comparison of AM fungal species richness, diversity and species evenness in the 4 vegetation zones

Species richness, diversity and species evenness of AM 

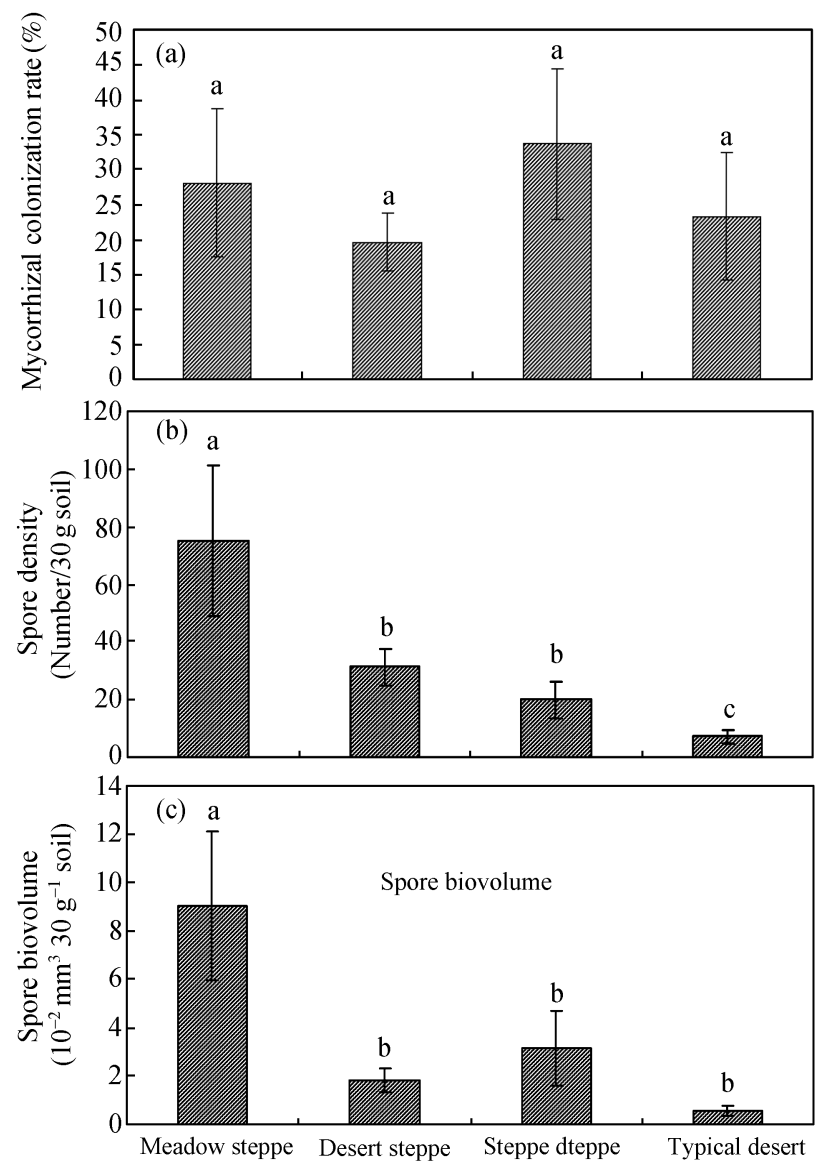

Figure 1 Mean mycorrhizal colonization rate (a), spore density (b) and biovolume (c) of AM fungi in 4 different vegetation zones. Error bars denote \pm SE. Mean values with the same letter are not significantly different by LSD at the $5 \%$ level.

fungi were calculated to give the values in Figure 2. Species richness and diversity of AM fungi showed similar trends, with the highest values in meadow steppe and lowest in typical desert (Figure 2(a), (b)). AM fungal species evenness did not show any significant differences among the 4 vegetation types (Figure 2(c)).

\subsection{Comparison among AM fungal species}

All 28 AM fungal species belonging to three genera, including 1 species of Archaeospora, 5 in Acaulospora and 22 in Glomus, were isolated and identified in rhizosphere soil samples from the 4 vegetation types on the northern slopes of the Tianshan Mountains (Table 3).

Meadow steppe, steppe desert and typical desert had 14, 12 and 14 species, respectively, representing $3 \mathrm{AM}$ fungal genera. Only Glomus species (13 total) were isolated and identified from desert steppe, with no species of Archaeospora or Acaulospora detected. Among the 28 AM fungal species, only 5 ( $G$. aggregatum, $G$.
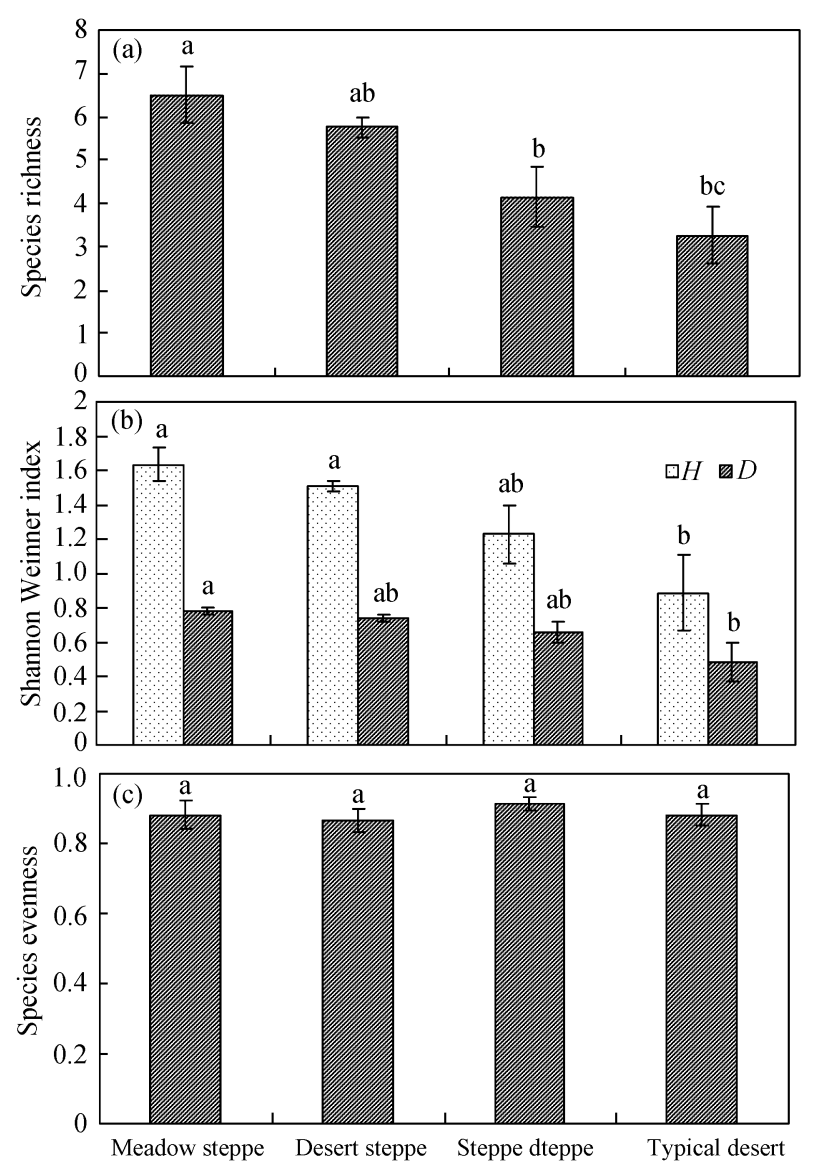

Figure 2 Species richness (a), diversity (b) and equality of uniformity (c) of AM fungi in the 4 vegetation types. Error bars denote \pm SE. Mean values with the same letter are not significantly different by LSD at the $5 \%$ level. $H$, Shannon-Weiner index; $D$, Simpson index.

claroideum, G. deserticola, G. etunicatum and G. sinuosum) were observed in all 4 vegetation zones.

\section{Discussion}

AM fungi are ecologically important root symbionts of most terrestrial plants. They are a critical component of terrestrial ecosystems and can have important effects on nutrient acquisition by most land plants. Additionally, colonization by AM fungi can increase plant survivorship under abiotic and biotic stresses such as soil disturbance, biological invasion and environmental pollution. So far, more than 200 AM fungi species have been identified and reported. The distributions of some species are very wide, including mountains, grasslands and arid areas ${ }^{[30,31]}$. The International Bank for the Glomeromycota (IBG (http: //www.bio.ukc.ac.uk/beg/)) states, "The majority of plants, strictly speaking, do not have roots; they have mycorrhizas. The study of plants without their 
Table 2 Mycorrhizal colonization rates of each host plant species and spore densities of their rhizosphere soils in 4 different vegetation zones ${ }^{1)}$

\begin{tabular}{|c|c|c|}
\hline Zonal type/Host plant species & $\begin{array}{c}\text { Mycorrhizal colonization rate } \\
\text { (percentage of root length colonized) }\end{array}$ & $\begin{array}{c}\text { Spore density } \\
\text { (Number/30 g soil) }\end{array}$ \\
\hline \multicolumn{3}{|l|}{ Meadow steppe } \\
\hline Potentilla sp. & $36.7 \mathrm{c}$ & $30 \mathrm{c}$ \\
\hline Stipa capillata & $2.9 \mathrm{~h}$ & $60 \mathrm{~b}$ \\
\hline Androsace sp. & $52.2 \mathrm{~b}$ & $60 \mathrm{~b}$ \\
\hline Taraxacum sp. & $20.5 \mathrm{def}$ & $150 \mathrm{a}$ \\
\hline \multicolumn{3}{|l|}{ Desert steppe } \\
\hline Allium polyrrhizum & 26.4 cde & $30 \mathrm{c}$ \\
\hline Orostachys sp. & $27.3 \mathrm{~cd}$ & $25 \mathrm{c}$ \\
\hline Cleistogenes songgorica & $12.6 \mathrm{fgh}$ & $50 \mathrm{~b}$ \\
\hline Stipa glareosa & $12.2 \mathrm{fgh}$ & 20 cde \\
\hline \multicolumn{3}{|l|}{ Steppe desert } \\
\hline Ceratoides latens & $3.7 \mathrm{~h}$ & $30 \mathrm{c}$ \\
\hline Salsola arbuscula & $12.0 \mathrm{fgh}$ & $50 \mathrm{~b}$ \\
\hline Allium polyrrhizum & $20.2 \mathrm{defg}$ & $20 \mathrm{cde}$ \\
\hline Cleistogenes songgorica & $58.7 \mathrm{~b}$ & $4 \mathrm{f}$ \\
\hline Plantago minuta & $84.5 \mathrm{a}$ & $4 \mathrm{f}$ \\
\hline Trigonella arcuata & $35.2 \mathrm{c}$ & $11 \mathrm{def}$ \\
\hline Nonea caspica & $22.0 \mathrm{def}$ & 20 cde \\
\hline \multicolumn{3}{|l|}{ Typical desert } \\
\hline Plantago minuta & $15.3 \mathrm{efgh}$ & $1 \mathrm{f}$ \\
\hline Erodiun oxyrrhynchum & $36.0 \mathrm{c}$ & $23 \mathrm{~cd}$ \\
\hline Cancrinia discoidea & $15.3 \mathrm{efgh}$ & $4 \mathrm{f}$ \\
\hline Heliotropium ellipticum & $7.6 \mathrm{~h}$ & 8 ef \\
\hline Lactuca $\mathrm{sp}$ & $8.0 \mathrm{gh}$ & $3 \mathrm{f}$ \\
\hline Eremopyrum orientale & $83.1 \mathrm{a}$ & $6 \mathrm{f}$ \\
\hline Arnebia guttata & $10.3 \mathrm{fgh}$ & $4 \mathrm{f}$ \\
\hline Atriplex dimorphostegia & $11.0 \mathrm{fgh}$ & 8 ef \\
\hline
\end{tabular}

1) Within each column, mean values followed by the same letter are not significantly different by LSD at the $5 \%$ level.

Table 3 AM fungal species in the different zonal types ${ }^{1)}$

\begin{tabular}{|c|c|c|c|c|}
\hline AM fungal species & Meadow steppe & Desert steppe & Steppe desert & Typical desert \\
\hline Acaulospora. bireticulata Rothwell \& Trappe & & & + & \\
\hline A. denticulata Sieverding \& Toro & + & & & \\
\hline A. elegans Trappe \& Gerdemann & & & + & \\
\hline A. foveata Trappe \& Janos & + & & & \\
\hline A. scrobiculata Trappe & + & & & \\
\hline Archaeospora leptoticha (Schenck \& Smith) Morton \& Redecker & + & & + & + \\
\hline Glomus aggregatum Schenck \& Smith & + & + & + & + \\
\hline G. caledonium (Nicol. \& Gerd.) Trappe \& Gerd. & + & + & & \\
\hline G. canadense (Thaxter) Trappe \& Gerd. & & & & + \\
\hline G. chimonobambusae Wu \& Liu & & & & + \\
\hline G. claroideum Schenck \& Smith & + & + & + & + \\
\hline G. clarum Nicol. \& Schenck & & + & & + \\
\hline G. deserticola Trappe, Bloss \& Menge & + & + & + & + \\
\hline G. etunicatum Becker \& Gerdemann & + & + & + & + \\
\hline G. fulvum (Berk. \& Broome) Trappe \& Gerd. & & & & + \\
\hline G. geosporum (Nicol. \& Gerd.) Walker & & & + & + \\
\hline G. halonatum Rose \& Trappe & + & & & \\
\hline G. hoi Berch \& Trappe & & + & & \\
\hline G. lacteum Rose \& Trappe & & + & & \\
\hline G. macrocarpum Tulasne \& Tulasne & + & & & + \\
\hline G. microaggregatum Koske, Gemma \& Olexia & + & & + & \\
\hline G. microcarpum Tulasne \& Tulasne & & + & + & + \\
\hline G. mosseae (Nicol. \& Gerd.) Gerd. \& Trappe & + & & + & \\
\hline G. nanolumen Koske \& Gemma & & & & + \\
\hline G. reticulatum Bhattacharjee \& Mukerji & & + & & \\
\hline G. sinuosum (Gerd. \& Bakshi) Almeida \& Schenck & + & + & + & + \\
\hline G. trimurales Koske \& Halvorson & & + & & \\
\hline G. verruculosum Blaszkowski & & + & & \\
\hline
\end{tabular}

1) + , AM fungi were present in soil samples. 
mycorrhizas is the study of artefacts".

AM fungi form associations with plant roots and, therefore, they are inevitably affected by their host plants $^{[32,33]}$ and by environmental factors ${ }^{[34-36]}$. All common plant species in the 4 vegetation types on the northern slopes of the Tianshan Mountains were found to form arbuscular mycorrhizal associations, indicating that AM fungi are widely distributed in the region. The high mycorrhizal colonization rates found in all 4 zonal types indicate that AM fungi may play an important role in the ecology of the host plants. Extensive mycorrhizal hyphal networks in the soil may provide an important pathway for the flow of nutrients and energy between plants ${ }^{[37-40]}$. However, the mycorrhizal colonization rate differed among host plant species and vegetation types; the mycorrhizal colonization rate of the same plant species varied among the vegetations zones. For example, mycorrhizal colonization rates of Plantago minuta averaged $84.5 \%$ in steppe desert and $15.3 \%$ in typical desert. AM fungal biological yield may be expressed by spore densities and biovolumes ${ }^{[27]}$. Similar trends were observed in both spore density and biovolume in the 4 vegetation types as evidenced by their significant positive relationship $(r=0.81, p<0.01)$. The present findings indicate that mycorrhizal colonization rates and spore densities are influenced not only by different host plants, but also by different environmental conditions in accordance with the conclusions of Wang et al. ${ }^{[41]}$.

1 Chapin F S, Mooney H A, Matson P A. Principles of Terrestrial Ecosystem Ecology. New York: Springer Verlag: 2002. 1-472

2 Marschner H. Mineral Nutrition of Higher Plants. 2nd ed. London, Academic Press, 1995. 1-889

3 Smith S E, Read D J. Mycorrhizal Symbiosis. London: Academic Press, 1997. 1-378

4 Rillig M C. Arbuscular mycorrhizae and terrestrial ecosystem processes. Ecol Lett, 2004, 7: 740-754

5 O'Neill E G, O’Neill R V, Norby R J. Hierarchy theory as a guide to mycorrhizal research on large-scale problems. Environ Pollut, 1991, 73: $271-284$

6 Redecker D, Kodner R, Graham L E. Glomalean fungi from the Ordovician. Science, 2000, 289: 1920-1921

7 Rillig M C, Allen M F. What is the role of arbuscular mycorrhizal fungi in plant-to-ecosystem responses to elevated atmospheric $\mathrm{CO}_{2}$ ? Mycorrhiza, 1999, 9: 1-8

8 Fitter A H, Heinemeyer A, Staddon P L. The impact of elevated $\mathrm{CO}_{2}$ and global climate change on arbuscular mycorrhizas: a mycocentric approach. New Phytol, 2000, 147: 179-187

9 Treseder K K, Allen M F. Mycorrhizal fungi have a potential role in
Species richness and diversity of AM fungi differed among the 4 vegetation zones. This difference may be due to both host plant species and environmental factors because many studies have shown that soil organic matter content and available $\mathrm{P}$ and altitude significantly affect the diversity of AM fungi ${ }^{[35,42-44]}$. The differences in AM fungal diversity and species richness between meadow steppe and typical desert may be attributable to soil nutrients, rather than altitude of host plant species, because the soil organic matter and available $\mathrm{P}$ contents were higher in meadow steppe than in typical desert. No significant differences in AM fungal species evenness were observed among the 4 different vegetation zones.

The 28 AM fungal species representing three genera were isolated from the rhizosphere soils of the most common plant species and identified. 22 species of Glomus appeared to be dominant on the northern slopes of the Tianshan Mountains. In contrast, Archaeospora and Acaulospora represented only $3.6 \%$ and $17.9 \%$ of the species present. This provides strong support for the conclusions of other researchers, who have suggested that Glomus species tend to be the dominant AM fungi in arid ecosystems. In addition, the genus Glomus is the largest of all the AM fungal genera in the Glomales ${ }^{[45]}$. No relationship was found between root colonization rate and spore density among the 4 vegetation types $(r=-0.15, p>0.05)$ and this finding agrees with some previous reports from studies in other ecosystems ${ }^{[46,47]}$.

soil carbon storage under elevated $\mathrm{CO}_{2}$ and nitrogen deposition. New Phytol, 2000, 147, 189-200

10 Rillig M C, Treseder K K, Allen M F. Global change and mycorrhizal fungi. In: van der Heijden M A, Sanders I R, eds. Mycorrhizal Ecology. Ecol Stud, 2002,157: 135-160

11 Hamel C. Prospects and problems pertaining to the management of arbuscular mycorrhizae in agriculture. Agric Ecosyst Environ, 1996, 60: $197-210$

12 Jansa J, Mozafar A, Kuhn G, et al. Soil tillage affects the community structure of mycorrhizal fungi in maize roots. Ecol Appl, 2003, 13: $1164-1176$

13 Oehl F, Sieverding E, Ineichen K, et al. Impact of land use intensity on the species diversity of arbuscular mycorrhizal fungi in agroecosystems of central Europe. Appl Environ Microbiol, 2003, 69: 28162824

14 Meharg A A, Cairney J W G. Co-evolution of mycorrhizal symbionts and their hosts to metal-contaminated environments. Adv Ecol Res, 2000, 30: 70-102

15 Egerton-Warburton L M, Allen, E B. Shifts in arbuscular mycorrhizal fungal communities along an anthropogenic nitrogen deposition gra- 
dient. Ecol Appl, 2000, 10: 484-496

16 Melillo J M, Kicklighter D W, McGuire A D, et al. Global climate change and terrestrial net primary production. Nature, 1993, 363: $234-240$

17 Lcehle C, Leblanc D. Model-based assessments of climate change effects on forest: a critical review. Ecol Model, 1996, 90: 1-31

18 ZhengY R, Zhou G S, Zhang X S, et al. Sensitivity of terrestrial ecosystem to global change in China. Acta Bot Sin (in Chinese), 1997, 39(9): $837-840$

19 Chen X, Luo G P, Xia J, et al. Ecological response to the climate change on the northern slope of the Tianshan Mountains in Xinjiang. Sci China Ser D-Earth Sci, 2005, 48(6): 765-777

20 Klironomos J N, McCune J, Hart M, et al. The influence of arbuscular mycorrhizae on the relationship between plant diversity and productivity. Ecol Lett, 2000, 3: 137-141

21 Ye B S, Ding Y J, Kang E S, et al. Responses of the snowmelt runoff to the climate becoming warming-up in the last 40 years in Xinjiang Autonomous region, China. Sci China Ser D-Earth Sci, 1999, 42(Suppl): 44-51

22 Luo G P, Chen X, Zhou K F, et al. Temporal and spatial variation and stability of the oasis in the Sangong River Watershed. Sci China Ser D-Earth Sci, 2003, 46(1): 62-73

23 Shi Y F, Shen Y P, Hu, R J. Preliminary study on signals, impact and foreground of climatic shift from warm-dry to warm-humid in Northwest China. J Glaciol Geocry (in Chinese), 2002, 24(3): $219-226$

24 Biermann B, Linderman R G. Quantifying vesicular arbuscular mycorrhizae: a proposed method towards standardization. New Phytol, 1981, 87: $63-67$

25 McGonigle T P, Miller M H, Evans D G, et al. A new method which gives an objective measure of colonization of roots by vesicular arbuscular mycorrhizal fungi. New Phytol, 1990, 115: 495-501

26 Dalpe Y. Vesicular-arbuscular mycorrhiza. In: Carter M R, ed. Soil Sampling and Methods of Analysis. Boca Raton: Lewis Publishers, 1993. $287-301$

27 Wolf J, Johnson N C, Rowland D L, et al. Elevated $\mathrm{CO}_{2}$ and plant species richness impact arbuscular mycorrhizal fungal spore communities. New Phytol, 2003, 157: 579-588

28 Schenk N C, Perez Y. Manual for Identification of VA Mycorrhizal Fungi. Gainesville: Synergistic Publications, 1990. 1-255

29 Morton J B, Redecker D. Two new families of Glomales, Archaeosporaceae and Paraglomaceae, with two new genera Archaeospora and Paraglomus, based on concordant molecular and morphological characters. Mycologia, 2001, 93: 181-195

30 Schönbeck F. Endomycorrhiza: Ökologie, Funktion und phytopathologische Aspekte. Forum Mikrobiol, 1980, 3: 90-96

31 Bonfante-Fasolo P, Scannerini S. The cellular basis of plant-fungus interchanges in mycorrhizal associations. In: Allen M F. Mycorrhizal Functioning. New York: Chapman \& Hall, 1992. 65-101
32 Burrows R, Pfleger F. Arbuscular mycorrhizal fungi respond to increasing plant diversity. Can J Bot, 2002, 80: 120-130

33 Eom A, Hartnett D C, Wilson G. Host plant species effects on arbuscular mycorrhizal fungal communities in tallgrass prairie. Oecologia, 2000, 122: 435-444

34 Rasmussen H, Anderson T F, Johansen B. Temperature sensitivity of in vitro germination and seedling development of Dactylorhiza majalis (Orchidaceae) with and without mycorrhizal fungus. Plant Cell Environ, 1990, 13 (2): 171-177

35 Zhang M Q, Wang Y S, Zhang C, et al. The ecological distribution characteristics of some genera and species of VAM fungi in Northern China. Acta Mycol Sin (in Chinese), 1994, 13 (3): 166-172

36 Schwob I, Ducher M, Coudret A. Effects of climatic factors on native arbuscular mycorrhizae and Meloidogyne exigua in a Brazilian rubber tree (Hevea brasiliensis) plantation. Plant Pathol, 1999, 48: $19-25$

37 Fitter A H, Graves J D, Watkins N K, et al. Carbon transfer between plants and its control in networks of arbuscular mycorrhizas. Funct Ecol, 1998, 12: 406-412

38 Robinson D, Fitter A. The magnitude and control of carbon transfer between plants linked by a common mycorrhizal network. J Exp Bot, 1999, 50: 9-13

39 Booth M G. Mycorrhizal networks mediate overstorey-understorey competition in a temperate forest. Ecol Lett, 2004, 7: 538-546

40 Southworth D, He X H, Swenson W, et al. Application of network theory to potential mycorrhizal networks. Mycorrhiza, 2005, 15(8): $589-595$

41 Wang F Y, Liu R J, Lin X G, et al. Arbuscular mycorrhizal status of wild plants in saline-alkaline soils of the Yellow River Delta. Mycorrhiza, 2004, 14: 133-137

42 Pan X L, Wang Y J, Zhang Y G, et al. The preliminary investigation of vesicle-arbuscular mycorrhizal fungal spore quantity in the Loess Plateau. Act Pedol Sin (in Chinese) 1994, 31(Suppl): 64-70

43 Joner E J, Jakobsen I. Contribution and extracellular phosphate activity of arbuscular mycorrhizal hyphae as influence by soil organic matter. Soil Biol Biochem, 1995, 27(9): 1153-1159

44 Verma R K, Arya I D. Effect of arbuscular mycorrhizal fungal isolates and organic manure on growth and mycorrhization of micropropapated Dendrocalamus asper plantlets and on spore production in their rhizosphere. Mycorrhiza, 1998, 8 (2): 113-116

45 Schwarzott D, Walker C, Schüßler A. Glomus, the largest genus of the arbuscular mycorrhizal fungi (Glomales), is nonmonophyletic. Mol Phylogen et Evol, 2001, 21(2): 190-197

46 Zhang Y, Guo L D, Liu R J. Arbuscular mycorrhizal fungi associated with common pteridophytes in Dujiangyan, southwest China. Mycorrhiza, 2004, 14: 25-30

47 Shi Z Y, Chen Y L, Feng G, et al. Arbuscular mycorrhizal fungi associated with the Meliaceae on Hainan island, China. Mycorrhiza, 2006, 16: $81-87$ 